\title{
Mangrove Cultivation (Avicennia Marina) as an Effort for Mangrove Rehabilitation in the Ponds Bare in Belopa, Luwu Regency
}

\author{
Bustam Sulaiman ${ }^{1,4}$, Azis Nur Bambang ${ }^{1,2,3}$, Mohammad Lutfi $^{5}$ \\ ${ }^{1}$ Doctorate Program of Environmental Science, School of Post Graduate Studies, Diponegoro University, Semarang, 50275, Indonesia \\ ${ }^{2}$ Faculty of Fishery and Ocean, Diponegoro University, Semarang, 50275, Indonesia \\ ${ }^{3}$ Master Program of Environmental Science, School of Post Graduate Studies, Diponegoro University, Semarang, 50275,Indonesia \\ ${ }^{4}$ Department of Oil and Gas Processing Engineering, STT MIGAS, Balikpapan, 76127, Indonesia \\ ${ }^{5}$ Department of Petroleum Engineering, STT MIGAS, Balikpapan, 76127, Indonesia
}

\begin{abstract}
Mangrove forest suggest a high degradation rate due to its utilization pattern which is ignore conservation aspect. In order to manage of mangrove forests in a sustainable manner, it is required any knowledge about the economic values which is useful for local community. This study aims to rehabilitate mangrove forests in Belopa, Luwu regency that have been turned into ponds by planting Avicennia marina mangroves around the ponds to expand land cover in the empty ponds and its fruit can be utilized for processed foods. This research is the action research. Estimated area of mangrove cover that is more than 10 years old is estimated that in each hectare of ponds will cover of about $2000 \mathrm{~m}^{2}(20 \%), 3000 \mathrm{~m}^{2}(30 \%)$ and $4000 \mathrm{~m}^{2}(40 \%)$ with the distance of each tree is 4 meters in one hectare, the total tree in one hectare is 100 trees (pond 1), 150 trees (pond 2), 200 trees (pond 3) and 200 trees (pond 4).
\end{abstract}

\section{Introduction}

The rate of local poverty, and high levels of coastal degradation (including degradation of mangrove areas), low infrastructure quality are the problems being faced in Indonesia [1]. This case also occurred in Belopa, the coastal area of Luwu Regency, South Sulawesi Province, Indonesia.

Mangrove forest in Indonesia is one of the largest carbon-rich forests in the world. This saves more than three times the average carbon per hectare of tropical rainforest [2]. It contributes for $1 / 3$ of the global coastal carbon stock [3]. Several studies related to technology in reducing carbon footprint have been widely carried out $[4,5]$. The importance of public awareness to plant mangrove forests in terms of reducing the effects of greenhouse gases to the coastal ecosystems due to the development of ponds is very important to be concerned [6]. One of the methods is toreduce disaster due to hydrometeorological phenomena is by using numerical hydrodynamics modeling $[7,8]$.

Mangroves have great potential for social and economic development in coastal areas, therefore, it should have a good plan for its growth and sustainability. There are many ecological functions of mangrove forests, namely, providing nutrition for aquatic biota and nurseries for various biota, preventing abrasion, typhoon attacks [9], reducing the impact of tsunamis, and as waste absorption which comes from the river and the sea [10].

In previous research [11], it was revealed that there were still many fishermen who did not know the many benefits of mangroves for economic growth, ecology, ecotourism etc.

Rehabilitation of mangrove forests is an environmentally friendly protection effort that involves the community to foster a sense of ownership and a sense of responsibility in protecting natural resources [12].

There are two considerations for mangrove rehabilitation. Firstly, focus on institutions related to policies, planning, goals, objectives, and development strategies; and secondly, is the implementation of biophysical systems that lead to the implementation of rehabilitation [13].

A. marina can be used as food ingredients. The fruit can be processed into tasty and crispy chips like peas and melinjo chips. A study revealed that the composition of seeds contained $10.8 \%$ protein and $21.4 \%$ carbohydrates, so that the seeds of the plant could be used as an alternative food. Protein can be utilized in the body as a source of cell nutrition to grow and develop. With a small amount of fat in the seeds, it is less likely to get fatsoluble vitamins (A, D, E, and K). Conversely, the high water content in the seeds could be used to get higher water-soluble vitamins ( $\mathrm{B}$ and $\mathrm{C}$ ). Test results on levels

\footnotetext{
* Corresponding author: bustams@gmail.com
} 
of vitamin $\mathrm{B}$ and $\mathrm{C}$ in $A$. marina seeds revealed higher results, namely $\mathrm{B}$ vitamins in seeds $3.74 \mathrm{mg} / 100 \mathrm{~g}$ of ingredients and vitamin $\mathrm{C}$ was $22.24 \mathrm{mg} / 1 \mathrm{~g}$ of ingredients. The content of these two vitamins revealed that $A$. marina seeds as food ingredients are also able to meet the needs of several vitamins $\mathrm{B}$ and $\mathrm{C}$ needed by the body. The nutrition content comprises carbohydrates, protein, fiber, water, ash, $\mathrm{Fe}, \mathrm{Mg}, \mathrm{K}, \mathrm{Ca}$, vitamin $\mathrm{B}$, and vitamin $\mathrm{C}$ [14]. It can be processed to become sponge, gelatin, and various foods such as onde-onde, bingka, ketimus, dawet, combra, keripik, crackers, teng cake, gemblong, pudding, lala, candil, kolak. [15].

Mangrove cultivation of $A$. mariana is relatively easy to be conducted due to all types of mangrove flora have seeds or fruit that can float, so it can be dispersed by the flow of water. In addition, many of the types of mangroves are viviparous, where the seeds have germinated before the fruit falls from the tree [16] caused by gravity [17].

Based on the background described above, the results of this research are expected to create self-awareness and strong will especially among the local people to expand mangrove land cover in terms of supporting the low carbon society program in the worldwide.

\section{Method}

This research method is a direct action, where mangrove forest areas that have been planted can be rehabilitated by planting A Marina mangrove trees at an open pond. The empty ponds will be planted with mangroves around the ponds with a distance of planted, 4 meters per tree. Simulation model 1 in one hectare can be planted with 100 trees, simulation model 2 is 150 trees, simulation model 3 is 200 trees, and simulation model 4 is 200 trees per hectare.
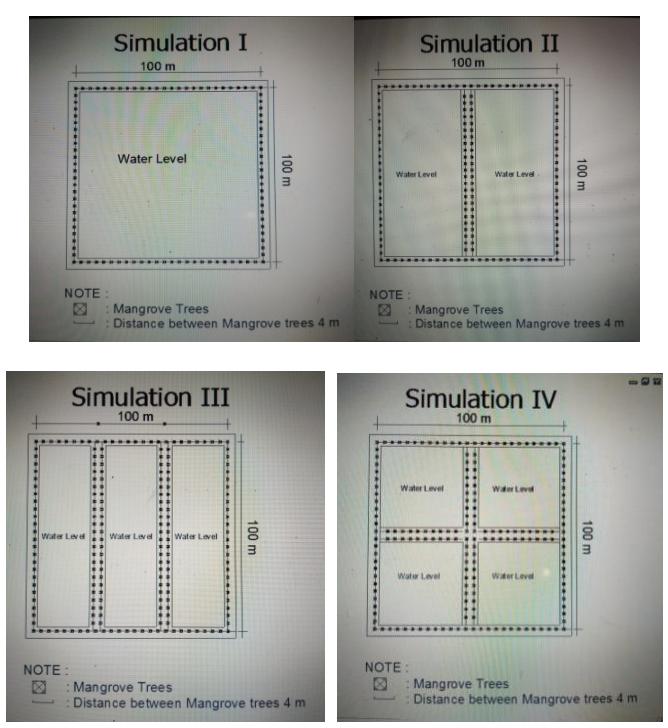

Fig. 1. Simulation model
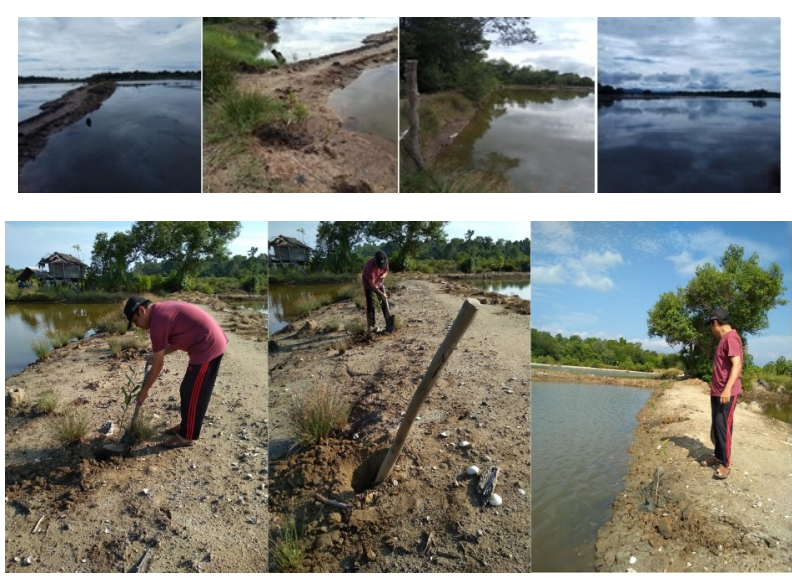

Fig. 2. Observation and direct action in the field

\section{Results And Discussions}

Table 1 shows that:

a. Simulation 1 for one hectare of area, with the number of plots is 1 , the number of trees is 100 , and estimated closure is $2000 \mathrm{~m}^{2}$.

b. Simulation 2 for one hectare, with the number of plots is 2 , the number of trees is 150 and estimated closure is 3000 $\mathrm{m}^{2}$.

c. Simulation 3 for one hectare, with the number of plots is 3 , the number of trees is 200 , and estimated closure is 4000 $\mathrm{m}^{2}$.

d. Simulation 4 for one hectare, with the number of plots is 4 , the number of trees is 200, and estimated closure is 4000 $\mathrm{m}^{2}$.

Table 1. The number of trees and estimated closure

\begin{tabular}{|c|c|c|c|c|}
\hline No & $\begin{array}{c}\text { Area } \\
\text { (ha) }\end{array}$ & $\begin{array}{c}\text { Number of } \\
\text { Plots }\end{array}$ & $\begin{array}{c}\text { Number of } \\
\text { Trees }\end{array}$ & $\begin{array}{c}\text { Estimated } \\
\text { closure }\left(\mathrm{m}^{2}\right)\end{array}$ \\
\hline 1 & 1 & 1 & 100 & 2000 \\
\hline 2 & 1 & 2 & 150 & 3000 \\
\hline 3 & 1 & 3 & 200 & 4000 \\
\hline 4 & 1 & 4 & 200 & 4000 \\
\hline
\end{tabular}

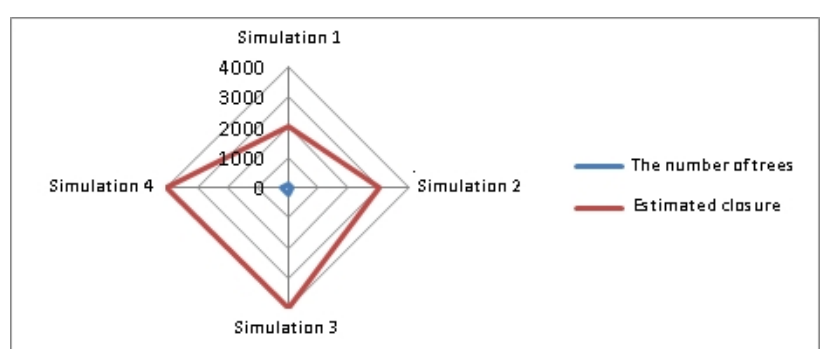

Fig. 3. Total cover and the number of trees in one hectare for each simulation

\section{Conclusions}

Mangrove rehabilitation was conducted by planting mangroves on empty ponds. Estimated cover at the age of mangroves more than ten years is 5 meters wide. In one hectare the distribution of one plot obtained a cover of $2000 \mathrm{~m}^{2}(20 \%)$ with a number of 100 trees, for the distribution of two plots in one hectare obtained $3000 \mathrm{~m}^{2}$ (30\%) with 150 trees, while for three plots and four plots, 
each $4000 \mathrm{~m}^{2}(40 \%)$ with a total of 200 trees. Mangroves can be processed into various types of processed foods, in order to increase the economic value of the plants for coastal communities and sustainable management in Belopa, Luwu regency which is in line with the low carbon society program in the world.

\section{References}

1. H. Purnaweni, Kismartini, S.P. Hadi, T. R. Soeprobowati. Challenges for the development of resilient coastal area program in Timbulsloko Village Sayung District Demak Regency, Advance Science Letter. 23, 3, (2017), pp. 2582-2583. https://doi.org/10.1166/asl.2017.8711

2. D. C. Donato, J. B. Kauffman, D. Murdiyarso, S. Kurnianto, M. Stidham, and M. Kanninen. Mangroves among the most carbon-rich forests in the tropics. Nature geoscience, 4, 5, (2011), p.293.

3. L. Pendleton, D. C. Donato, B. C. Murray, S. Crooks, W. A. Jenkins, S. Sifleet, C. Craft, J. W. Fourqurean, J. B. Kauffman, N. Marbà, and P. Megonigal. Estimating global "blue carbon" emissions from conversion and degradation of vegetated coastal ecosystems. PloS one, 7, 9, (2012).

4. M. Lutfi, M. Yamin, M. Rahman, and E. G. Popang. A comparative analysis of the quality of concrete blocks produced from coconut fibre, oil palm empty fruit bunch, and rice husk as filler material. MATEC Web of Conferences. 195, (2018), 01019, EDP Sciences. Doi. https://doi.org/10.1051/matecconf/201819501019

5. M. Yamin, Rudito, A. Lisnawati, and M. Lutfi. A preliminary study of the low density particle boards quality using rice husks and oil palm empty fruit bunch with plastic waste adhesive. MATEC Web of Conferences. 195, (2018), 01022. EDP Sciences. Doi. https://doi.org/10.1051/matecconf/201819501022

6. D. Murdiyarso, J. Purbopuspito, J. Kauffman, J.B. Warren, M.W. Sasmito, S.D. Donato, D.C. Manuri, S. Krisnawati, H. Taberina, S. Kurnianto. The potential of Indonesian mangrove forests for global climate change mitigation. Nature Climate Change 5, pp. 1089-1092 (2015). Doi: 10.1038/nclimate2734
7. M. Lutfi, R. S. Afifah, B. Sulaiman, Risna. Numerical simulation of hydrodynamic for abrupt bathymetry in Palu river estuary. Indian J. of Sci. and Tech, 10, 29, (2017). Doi: 10.17485/ijst/2017/v10i29/116502

8. Lutfi M. 2015. Three dimensional model for cohesive sediment transort in estuary of Palu river. Journal of Mitra Sains. 3, 1, ( 2015), pp. 78-87.

9. T. James, V. J. Savin, P. M. Claire, R. Md. Masumur, T. Arnel, M. Lutfi. Effectiveness of CAMANAVA flood control project : A case study of selected flood control structures during typhoon gener and monsoon rains in August. J. of IDEC, 19, 3 (2013) pp. 131145. Doi: http://doi.org/10.15027/35045

10. L. S. Hamilton, S. C. Snedaker. Handbook for mangrove area management. Honolulu: East-West Environment and Policy Institute. (1984)

11. B. Sulaiman, A. N. Bambang, H. Purnaweni, and M. Lutfi. The Effect of Mangrove on Fish Catch Using Belat at Teluk Pemedas and Sanipah of Kutai Kartanegara Regency, East Kalimantan Province, Indonesia. E3S Web of Conferences. 31, 08029, (2018). EDP Sciences. Doi. https://doi.org/10.1051/e3sconf/20183108029

12. O. Pontoh.. Peranan nelayan terhadap rehabilitasi ekosistem hutan bakau (mangrove). Jurnal Perikanan dan Kelautan Tropis, 7, 2, (2011), pp.73-79.

13. P. E. R. Dale, J. M. Knight, and P. G. Dwyer. Mangrove rehabilitation: a review focusing on ecological and institutional issues. Wetlands ecology and management, 22, 6, (2014), pp.587-604.

14. C. Kusmana, A. Suryani, Y. Hartati, and P. Oktadiyani. Pemanfaatan jenis pohon Mangrove apiapi (Avicennia spp) sebagai bahan pangan dan Obatobatan. (2009).

15. J. A. Duke. Avicennia marina (Forsk.Vierch). Handbook Of Energy Crops. (1983).

16. T. Mayor, H. E. Simbala, and R. Koneri. Biodiversitas Mangrove di Pulau Mansuar Kabupaten Raja Ampat Provinsi Papua Barat (The Biodiversity of Mangrove in the Mansuar Island Raja Ampat District West Papua Province). Bioslogos, 7, 2, (2018).

17. M. Lutfi. The effect of gravitational field on brachistochrone problem. Journal of Physics: Conference Series.. 1028, 1, (2018), 012060. IOP Publishing. doi :10.1088/1742-6596/1028/1/012060 